\title{
Interlaboratory comparison of fig (Ficus carica L.) microsatellite genotyping data and determination of reference alleles
}

\author{
Matjaž HLADNIK ${ }^{1}$, Jernej JAKŠE ${ }^{2}$, Bouchaib KHADARI ${ }^{3}$, Sylvain SANTONI $^{3}$, Dunja BANDELJ ${ }^{{ }^{*}}$
}

Received December 04, 2017; accepted January 24, 2018.

Delo je prispelo 04. decembra 2017, sprejeto 24. januarja 2018.

\begin{abstract}
Microsatellites have been identified as the marker of choice in plant genotyping projects. However, due to length discrepancies obtained between different laboratories for the same allele, interlaboratory comparison of fingerprinting results is often a difficult task. The objectives of this study were to compare genotyping results of two laboratories, to evaluate genetic parameters of microsatellite markers and to determine reference allele sizes for fig cultivars from the Istrian peninsula.

Genotyping results of ninety fig (Ficus carica L.) accessions were comparable between the laboratories despite differences observed when comparing electropherograms of different capillary electrophoresis systems. Differences in lengths of the same alleles were detected due to different PCR methods and laboratory equipment, but the distances between alleles of the same locus were preserved. However, locus FSYC01 exhibited one allele dropout which led to misidentification of 28 heterozygotes as homozygote individuals suggesting this locus as unreliable. Allele dropout was assigned to the tail PCR technology or to a touchdown PCR protocol.

Genotypes of twenty-four reference cultivars from the Istrian peninsula were confirmed by both laboratories. These results will contribute to the usage of markers with greater reliability, discrimination power and consequently, to more reliable standardization with other fig genotyping projects.
\end{abstract}

Key words: microsatellite marker; reference genotype; interlaboratory comparison; Ficus carica L.
IZVLEČEK

MEDLABORATORIJSKA PRIMERJAVA
REZULTATOV GENOTIPIZACIJE FIGE $Z$
MIKROSATELITSKIMI MARKERJI (Ficus carica L.)
IN DOLOČITEV REFERENČNIH ALELOV

Mikrosateliti so se izkazali kot zelo uporabni markerji pri genetskih raziskavah rastlin. Zaradi odstopanj dolžin enakih alelov $\mathrm{v}$ različnih laboratorijih, je primerjava rezultatov med laboratoriji pogosto težavna. Namen raziskave je bil primerjati rezultate genotipizacije dveh laboratorijev, ovrednotiti genetske parametre mikrosatelitskih markerjev in določiti dolžine referenčnih alelov za sorte fig istrskega polotoka.

Rezultati genotipizacije devetdesetih vzorcev fige (Ficus carica L.) so bili primerljivi med laboratorijema, kljub razlikam, ki smo jih opazili pri primerjavi elektroferogramov različnih sistemov kapilarnih elektroforez. Razlike med dolžinami enakih alelov med laboratorijema so bile odkrite zaradi različnih metod PCR in analitske opreme, vendar pa so bile razlike med aleli istega lokusa ohranjene. Pri lokusu FSYC01 smo ugotovili izpad alela, kar je privedlo do napačne identifikacije; namesto 28 heterozigotov smo posameznike določili kot homozigote. Ugotovljena lastnost nakazuje na nezanesljivost lokusa FSYC01. Izpad alela smo pripisali uporabi ekonomične metode PCR ali uporabi protokola PCR s postopnim nižanjem temperature prileganja začetnih oligonukleotidov.

Genotipi štiriindvajsetih referenčnih sort istrskega polotoka so bili potrjeni $\mathrm{v}$ obeh laboratorijih. Rezultati raziskave bodo prispevali $\mathrm{k}$ uporabi bolj zanesljivih mikrosatelitskih markerjev, $\mathrm{z}$ večjo močjo razlikovanja in posledično $\mathrm{k}$ zanesljivi standardizaciji rezultatov $\mathrm{z}$ drugimi genetskimi raziskavami fige.

Ključne besede: mikrosatelitski marker; referenčni genotip; medlaboratorijska primerjava; Ficus carica L.

1 Ph.D.,University of Primorska, Faculty of Mathematics, Natural Sciences and Information Technologies, Glagoljaška 8, SI-6000 Koper, Slovenia; *e-mail of the corresponding author: dunja.bandelj@upr.si

2 Ph.D.,University of Ljubljana, Biotechnical Faculty, Agronomy Department, Jamnikarjeva 101, SI-1000 Ljubljana, Slovenia

3 Ph.D.,National Institute of Agricultural Research (INRA), UMR Genetic Improvement and Adaptation of Mediterranean and Tropical Plants AGAP 1334, F-34070 Montpellier, France 


\section{INTRODUCTION}

The integration of DNA molecular marker technology into fingerprinting studies of agricultural plants is extremely widespread and has become a standard procedure. The techniques rely on independence from environmental factors and phenotype stage of the plant under investigation and are thus complementary to traditional approaches that often include laborious morphological evaluations.

Microsatellite markers combine several properties of an ideal molecular marker including high polymorphism in the number of tandem repeats, co-dominant inheritance, abundance in genome, excellent reproducibility and ease of use. They are also considered as a marker of choice in plant genetic research for many applications (e.g. diversity studies, paternity testing, mapping and fingerprinting studies) (Nybom et al., 2014). The employment of fluorescently labeled microsatellite markers in genotyping procedures significantly improves the throughput, automation and lowers the error rate (Wenz et al., 1998). However, the use of microsatellites can be costly due to the high price of fluorescent tags which must be carried by one of the primers in the primer pair. To overcome this problem, an inexpensive and flexible procedure was introduced with the three primer protocol incorporating the addition of modified locus specific primer and the universal fluorescent-labelled M13 (-21) primer (Schuelke, 2000). This method was used in multiple genotyping projects (Bandelj et al., 2004; Kyung-Ho et al., 2009; Mandel et al., 2011; Soriano et al., 2011) and it was recognized as a good economic alternative to conventional method.

Simple numerical output makes microsatellite technology very attractive for exchanging data among laboratories and for the establishment of global genotyping databases (De Valk et al., 2009), but several authors discuss the problem of consistency of microsatellite genotyping data in different laboratories and suggest standardization procedures for allele sizing (Cryer et al., 2006; De Valk et al., 2009; Deemer \& Nelson, 2010; Jones et al., 2008; Vemireddy et al., 2007). Variation in results among laboratories could be due to human factors, differing methodologies, technological limitations, poor DNA quality or locus specific properties, since some microsatellite markers are more prone to errors and produce more stutters (Deemer \& Nelson, 2010; Doveri et al., 2008; Ellis et al., 2011; Sutton et al., 2011; This et al., 2004). Genotyping errors are often neglected even though they affect the data and can markedly influence the biological conclusions (Pompanon et al., 2005).

Studies which compare genotyping results between laboratories have been performed on olive cultivars
(Olea europaea L.) (Baldoni et al., 2009; Doveri et al., 2008) and grapevines cultivars (Vitis vinifera L.) (This et al., 2004), while on figs (Ficus carica L.) which are recognized as underutilized fruit species, no such study has been published yet. With development of fig microsatellite markers (Ahmed et al., 2007; Bandelj et al., 2007; Giraldo et al., 2005; Khadari et al., 2001), they have been successfully used for genotyping fig genetic resources in Spain (Balas et al., 2014; Giraldo et al., 2008), Turkey (Caliskan et al., 2012), Tunisia (Abdelkrim et al., 2015; Chatti et al., 2010), France (Khadari, 2012), Morocco (Achtak et al., 2010; Khadari et al., 2005), California (Aradhya et al., 2010), Japan (Ikegami et al., 2009), and Egypt (Abou-Ellail et al., 2014). According to Zohary \& Spiegel-Roy (1975) the existing genetic diversity of figs reflects their domestication process, their complex pollination biology, exchange of cultivars between the growing regions, clonal propagation, and the coexistence of wild, feral, and cultivated forms in natural and agro ecosystems. A common germplasm database to support fig research should be available in order to solve the confusion in naming varieties (synonyms, homonyms), support management of fig genetic resources with genetic tools across all growing regions, and to facilitate the exchange of genotyping data among different laboratories. Several properties of figs as agricultural products support this need: (1) the economic potential of fig fruits (figs are widely cultivated in North African and Middle Eastern countries, where they represent a significant source of agricultural income); (2) the nutritional value and functional properties (high antioxidant content (Solomon et al., 2006), rich fibre content, vitamins, and minerals (Vinson et al., 2005)); and (3) special pollination biology (mutualism with fig wasps, different sexual systems, distinct flower formation, parthenocarpy, and the existence of all these forms in fig production).

In order to provide comparable results among fig genotyping projects and further evaluation of fig germplasms worldwide, our objectives in the present study are: (1) to compare the genotyping results of two laboratories with expertise in fig genotyping generated by different PCR methodologies employing either a conventionally labeled primer with fluorescent label in each primer pair or the economic method described by Schuelke (2000); (2) to publish reference allele sizes for local figs cultivars from the Istrian peninsula (the Northeast Adriatic coast); and (3) to discuss diversity parameters of selected microsatellite loci for use in cultivar identification and fig genetic resources investigations. 


\section{MATERIAL AND METHODS}

\subsection{Plant material}

Ninety fig accessions were analyzed in this study. Eighty-four accessions were provided by the Slovenian research group (University of Primorska, Koper - SI in continuation) including 60 accessions collected from the North and East Adriatic coast (hereafter referred to as feral or wild forms) and 24 cultivars from the Istrian Peninsula. Six accessions (four wild samples and two cultivars) from the Mediterranean ex situ collection in the Porquerolles Island (southern France) were provided by the French research group (INRA, Montpellier - FR in continuation).

\subsection{DNA extraction}

The SI research group extracted genomic DNA from leaves of 84 fig accessions by a modified cetyl trimethylammonium bromide (CTAB) method following the procedure described by Kump \& Javornik (1996). The FR research group extracted genomic DNA from leaves of six accessions with the DNeasy Plant Mini Kit (Qiagen, Hilden, Germany) according to the supplier's instructions and minor modification described by Achtak et al. (2010). DNA concentration was determined using the Invitrogen Qubit ${ }^{\circledR}$ Fluorometer (Turner Biosystems, Sunnyvale, CA, USA) and the Qubit dsDNA BR Assay Kit (Molecular Probes, Thermo Fisher Scientific, Carlsbad, CA, USA) by SI researchers and spectrofluorometry (GENios Plus, TECAN, Grödig, Austria) by the FR research group. Dilutions of DNA with a concentration of $50 \mathrm{ng} / \mu \mathrm{l}$ were prepared and exchanged between research groups. Both research groups analysed the same DNA of 90 accessions as described in the following sections.

\subsection{Microsatellite assay}

Six primer pairs from different sets of the developed microsatellites have been selected for the genotyping procedure: MFC1, MFC2, MFC3 (Khadari et al., 2001), MFC9 (Khadari B., Hochu I., Santoni S., unpublished data), LMFC30 (Giraldo et al., 2005) and FSYC01 (Ahmed et al., 2007). According to each group's laboratory equipment and preferences for different chemicals various individual strategies for optimization and generalization of PCR conditions were employed. In general, the FR group used a conventional method with each primer pair labeled with the required dye, while the SI group used the economic three-primer method developed by Schuelke (2000). PCR and electrophoresis conditions for individual microsatellite locus are summarized in Table S1 and Table S2. Primer sequences used for conventional and economic methods are listed in Table S3.

\subsection{Data analysis}

The software packages GeneMapper version 3.7 (FR) and 4.1 (SI) (Applied Biosystems, Foster City, CA, USA) were used for determination of allele sizes, peak intensities (in relative fluorescence units, rfu), banding patterns, and number of amplified alleles per primer pair. SPSS (IBM Corp. Released 2010. IBM SPSS Statistics for Windows, Version 19.0. Armonk, NY: IBM Corp.) were used to illustrate differences of peak balance (also peak height ratio or heterozygote balance). Peak balance was calculated for each heterozygous combination (at least five individuals per allele combination) according to Method \#2, developed by Leclair et al. (2004), and defined as the ratio of peak height of the longer allele over that of the shorter allele. For comparison of allele sizes standard deviation and range were calculated for each marker using Microsoft Excel (2010).

Genetic parameters were calculated for 90 samples over all six analyzed microsatellite loci. Expected heterozygosity $\left(\mathrm{H}_{\mathrm{e}}\right)$, observed heterozygosity $\left(\mathrm{H}_{\mathrm{o}}\right)$, probability of identity (PI), polymorphic information content (PIC) and test for deviation from HardyWeinberg equilibrium (HWE) across all loci (chi-square $\left(\chi^{2}\right)$ test, p-value was assessed using Bonferroni correction (Kalinowski et al., 2007)) using the CERVUS 3.0.7 and Identity 1.0 (Wagner \& Sefc, 1999) programs. Frequency of null alleles $\left(\mathrm{F}_{\text {null }}\right)$ was calculated with FreeNA (Chapuis \& Estoup, 2007) and $\mathrm{N}_{\mathrm{e}}$ was computed using GenAlEx 6.5 (Peakall \& Smouse, 2006, 2012). The mean error rate per locus $\left(e_{l}\right.$ $=m_{l} / n t$ ) was calculated as ratio between $m_{l}$, the number of single-locus genotypes including at least one allelic mismatch, and $n t$, the number of replicated single-locus genotypes (Pompanon et al., 2005).

The identification of the minimum number of markers required to distinguish all the observed multilocus genotypes was performed with the AMaCAID program written in the $\mathrm{R}$ language, using model one (Caroli et al., 2011). 


\section{RESULTS}

\subsection{Visual and morphological characterization of amplified alleles}

In order to assess visual characteristics of alleles amplified in both laboratories caused by instrument resolution, peak signal strength and peak morphology were examined. Altogether 33 different alleles were identified over six microsatellite loci in both laboratories.

The shape of the peaks and number of stutter bands were nearly the same for all alleles regardless of the methods used in each laboratory. The exceptions were the alleles of the LMFC30 locus, produced by the economic method, which exhibit more stuttering and additional $n+1$ peak (where $n$ indicates allele length), and at the MFC9 locus where higher stutter bands were observed. Alleles of the FSYC01 locus exhibited single stutter band in the FR laboratory, while the procedure in the SI lab yielded no stuttering but showed $n+1$ peak (Figure 1).

The peak signal strength for each locus resulting from two different amplification techniques showed noticeable differences with much lower intensity values recorded in the SI laboratory (Table 1). 
Locus FSYC01; Accession codes of the same sample: SLCV191/48F 2
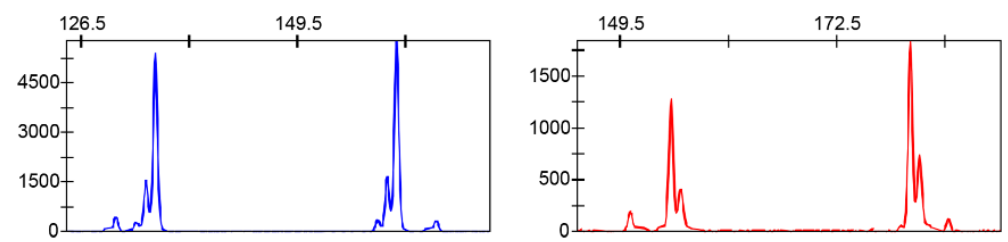

Locus LMFC30; Accession codes of the same sample: SLCV18/46F
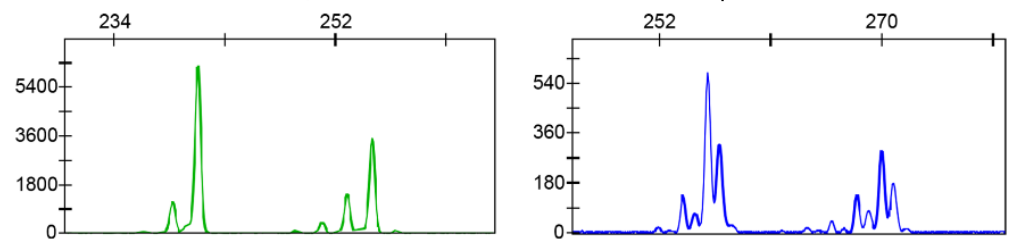

Locus MFC1; Accession codes of the same sample: SLCV05/17F
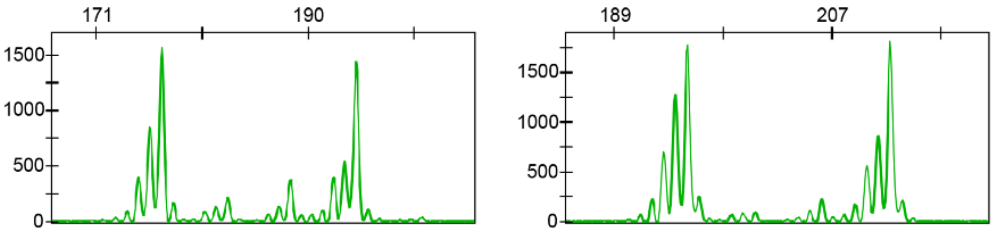

Locus MFC2; Accession codes of the same sample: SLCV20/49F
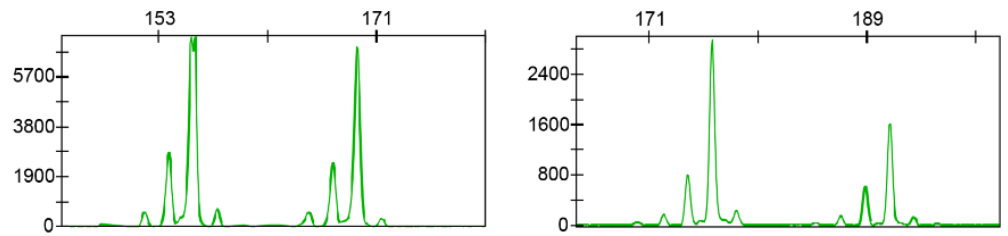

Locus MFC3; Accession codes of the same sample: SLCV13/36F
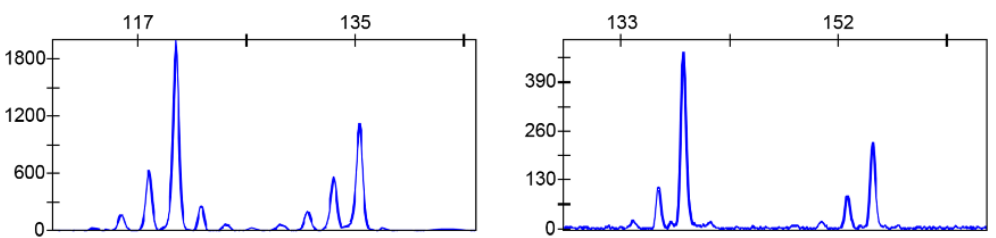

Locus MFC9; Accession codes of the same sample: SLCV03/10F
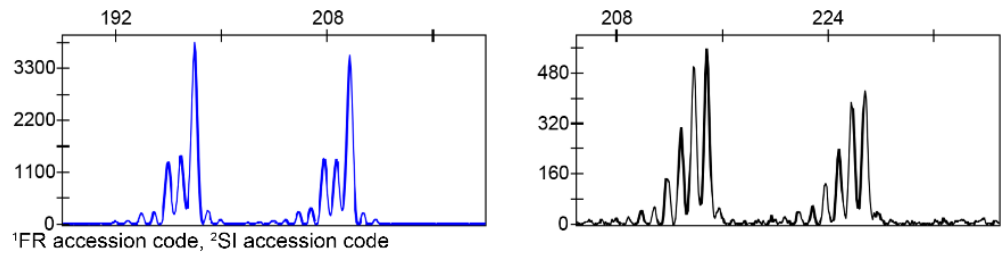

Figure 1: Allele patterns observed in the French research group (FR), on the left side, and in the Slovenian research group (SI), on the right side, at each locus. Heterozygous samples were chosen in order to present two alleles per sample.

Slika 1: Prikaz oblik alelov za vsak lokus, glede na elektroferograme francoske raziskovalne skupine (FR), prikazane na levi strani, in slovenske raziskovalne skupine (SI), prikazane na desni strani. 
Matjaž HLADNIK et al.

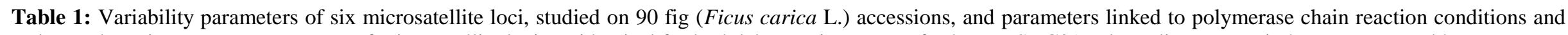

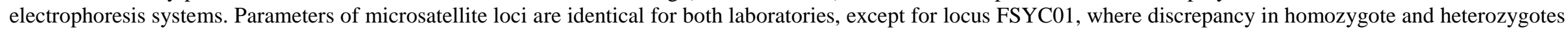
was found.

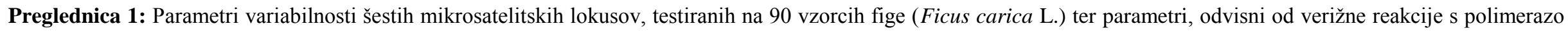

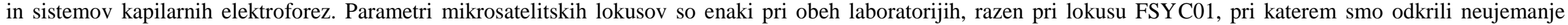
rezultatov pri določanju homozigotov in heterozigotov.

\begin{tabular}{|c|c|c|c|c|c|c|c|c|c|c|c|c|}
\hline \multirow[t]{2}{*}{ Locus } & \multirow[t]{2}{*}{$\mathrm{n}$} & \multirow[t]{2}{*}{$\mathrm{Ne}$} & \multirow[t]{2}{*}{ Ho } & \multirow[t]{2}{*}{$\mathrm{He}$} & \multirow[t]{2}{*}{ PIC } & \multirow[t]{2}{*}{ PI } & \multirow[t]{2}{*}{$\mathrm{F}_{\text {null }}$} & \multirow[t]{2}{*}{ HWE } & \multicolumn{2}{|c|}{$\begin{array}{l}\text { Average intensity } \\
\text { values (in rfu units) }\end{array}$} & \multicolumn{2}{|c|}{$\begin{array}{l}\text { Standard deviation of } \\
\text { peak intensity values }\end{array}$} \\
\hline & & & & & & & & & FR group & SI group & FR group & SI group \\
\hline FSYC01 & 5 & $\begin{array}{l}2.17 / \\
1.73^{\mathrm{SI}}\end{array}$ & $\begin{array}{l}0.544 / \\
0.256^{\text {SI }}\end{array}$ & $\begin{array}{l}0.539 / \\
0.423^{\mathrm{SI}}\end{array}$ & $\begin{array}{l}0.506 / \\
0.397^{\text {SI }}\end{array}$ & $\begin{array}{l}0.311 / \\
0.409^{\mathrm{SI}}\end{array}$ & $\begin{array}{l}0.00000 / \\
0.13976^{\text {SI }}\end{array}$ & $\begin{array}{l}0.4285 / \\
0.0002 \text { *** SI }\end{array}$ & 5186 & 2110 & 2087 & 737 \\
\hline LMFC30 & 8 & 5.25 & 0.833 & 0.810 & 0.782 & 0.118 & 0.00007 & 0.0603 & 5383 & 298 & 1605 & 176 \\
\hline MFC1 & 4 & 3.25 & 0.600 & 0.693 & 0.633 & 0.273 & 0.05099 & $0.0053^{*}$ & 2748 & 2215 & 1561 & 905 \\
\hline MFC2 & 5 & 2.76 & 0.667 & 0.683 & 0.571 & 0.331 & 0.00386 & 0.4867 & 6526 & 2068 & 1396 & 1022 \\
\hline MFC3 & 7 & 2.99 & 0.700 & 0.666 & 0.628 & 0.225 & 0.00000 & 0.4654 & 1912 & 269 & 813 & 128 \\
\hline MFC9 & 4 & 2.48 & 0.600 & 0.598 & 0.534 & 0.353 & 0.00003 & 0.4617 & 4569 & 605 & 1457 & 267 \\
\hline \multicolumn{6}{|c|}{ Combined PI for all loci } & $\begin{array}{l}2.66 \times 10^{-4} / \\
3.50 \times 10^{-4} \mathrm{SI} \\
\end{array}$ & & & & & & \\
\hline Average & 5.5 & $\begin{array}{l}3.15 / \\
3.07^{\mathrm{SI}}\end{array}$ & $\begin{array}{l}0.657 / \\
0.609^{\text {SI }}\end{array}$ & $\begin{array}{l}0.664 / \\
0.645^{\text {SI }}\end{array}$ & $\begin{array}{l}0.609 / \\
0.590^{\text {SI }}\end{array}$ & & & & & & & \\
\hline
\end{tabular}

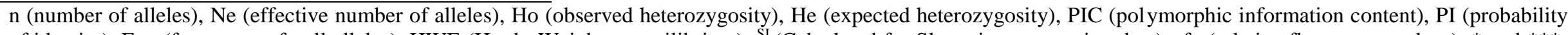

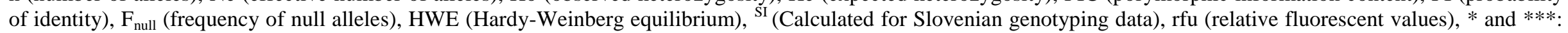
$p<0.05$ and $\mathrm{p}<0.001$ (chi-square test, significance with Bonferroni correction) 
The peak balance value was compared between laboratories to see the influence that distance between alleles in a heterozygote has on peak balance. In general, intensities were higher in shorter alleles for the majority of comparisons (peak balances lower than
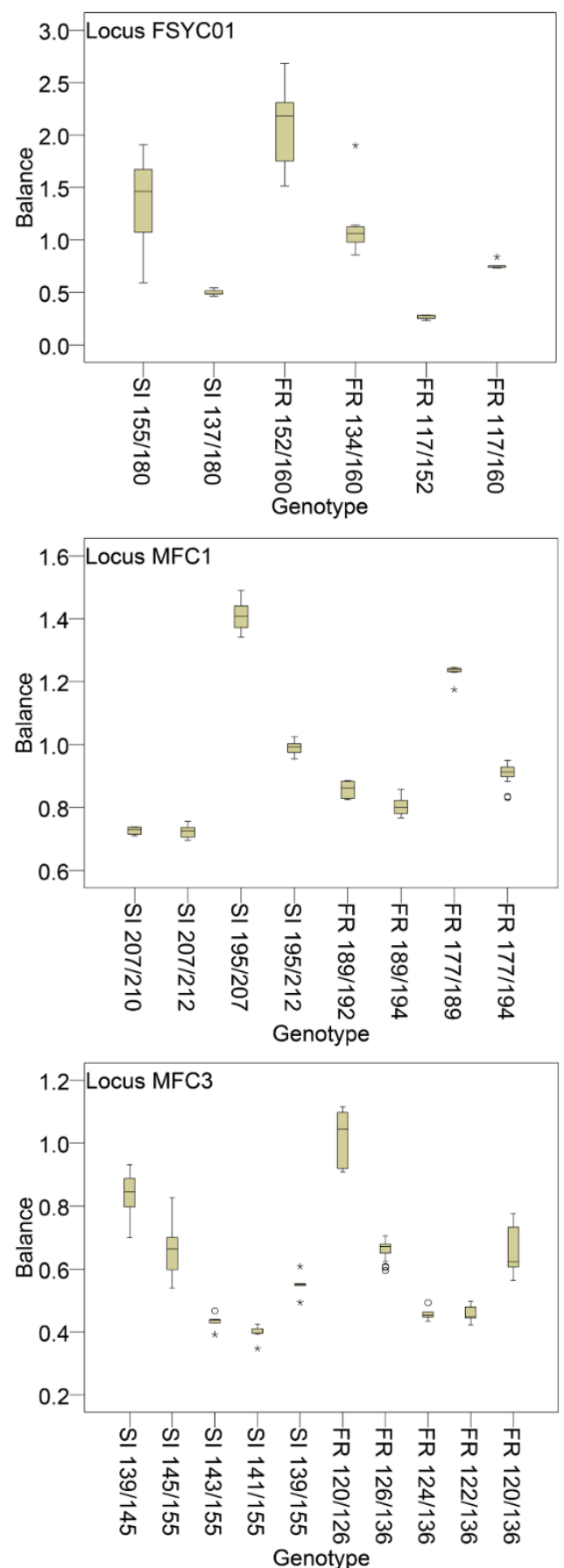

one). At two loci, LMFC30 and MFC3, the peak balance value was decreasing when the difference in allelic lengths was increasing (Figure 2). A similar pattern with similar peak balance values was observed in both the SI and FR laboratories.
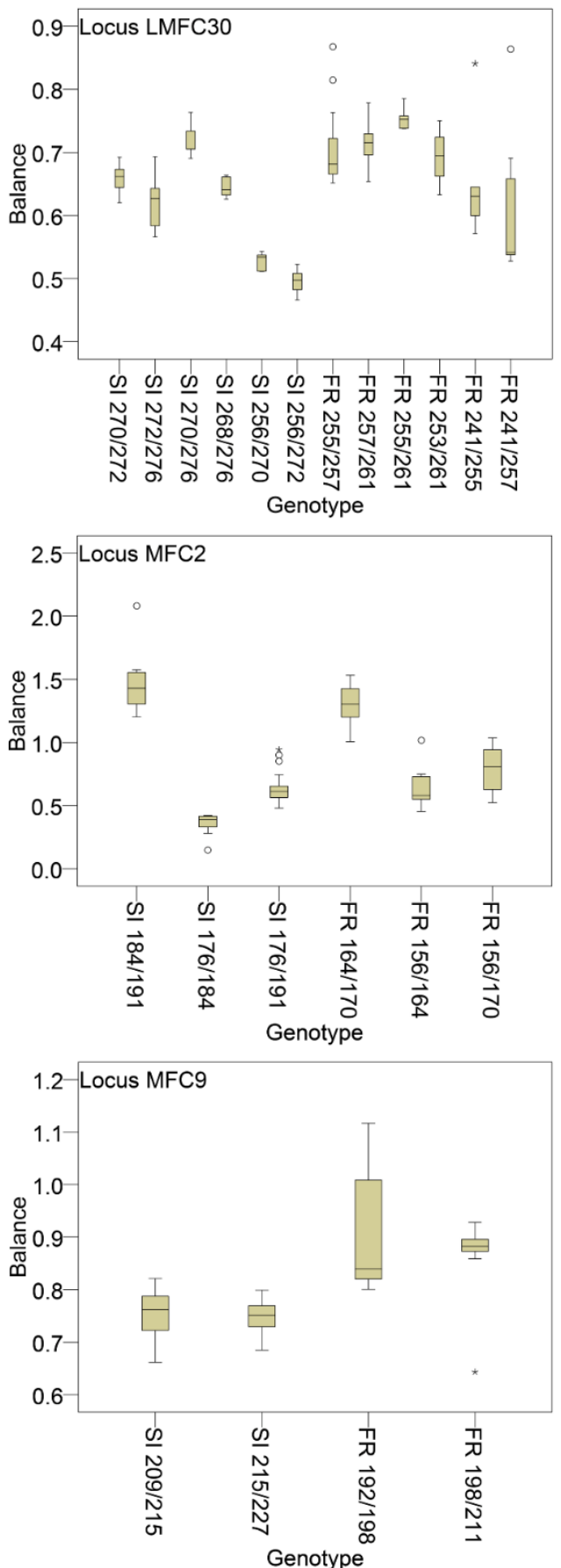

Figure 2: Box plots of peak balance values calculated for the Slovenian research group (SI) and French research group (SI) laboratories. Heterozygous samples with the same allele combinations were grouped together.

Slika 2: Prikaz vrednosti razmerij med intenziteto fluorescentnega signala daljšega in krajšega alela pri heterozigotih z okvirji z ročaji, na osnovi rezultatov slovenske (SI) in francoske (FR) raziskovalne skupine. Heterozigotni vzorci $\mathrm{z}$ enako kombinacijo alelov so uvrščeni $\mathrm{v}$ isto skupino. 


\subsection{Comparison of allele lengths among laboratories}

Actual allele sizes determined by the GeneMapper software were sorted according to their length to determine the groups of alleles which differ by less than $1 \mathrm{bp}$. Alleles were also manually reviewed and final sizes were rounded to the nearest full number representing the final called allele length. For easier comparison of genotypes between laboratories letters were also assigned to alleles, as suggested by Doveri et al. (2008), where A represents the shortest allele of the locus (Table 2). As expected, sizes of alleles between the laboratories differ (from $14.65 \mathrm{bp}$ to $21.44 \mathrm{bp}$ for actual lengths and $15 \mathrm{bp}$ to $21 \mathrm{bp}$ for called allele lengths) due to the distinct PCR technology, dye analysis matrices and internal standards used in analyses. The differences were consistent between alleles of the same locus.

The range between the minimum and maximum allele lengths were calculated as the simplest measure of variability. The highest difference of $1.02 \mathrm{bp}$ was observed at locus LMFC30 in FR data for allele $261 \mathrm{bp}$ $(\mathrm{H})$, while for SI data difference of $0.71 \mathrm{bp}$ was encountered at locus MFC1 for allele 212 (D). The range between actual allele sizes within the allele were relatively low with an average of $0.33 \mathrm{bp}$ and $0.23 \mathrm{bp}$ for the FR and SI teams, respectively.

Further comparison showed that the standard deviations for actual sizes of individual alleles were relative low, but varied among teams. Standard deviations were between 0.021 to 0.405 for alleles genotyped by the FR team, while somewhat lower standard deviations have been calculated for alleles scored by the SI team and were between 0.005 and 0.151 (Table 2). 
Table 2 List of alleles with average actual size, letter designation, total number of individual alleles used for calculation (n), standard deviation (SD), range, differences between average actual sizes obtained by Slovenian (SI) and French (FR) research group, differences between actual sizes after the removal of elongated primer sequence M13 (-21) and differences between allele sizes rounded to nearest integer with and without primer elongation sequences.

Preglednica 2: Seznam alelov s parametri: povprečna dejanska dolžina, črkovna oznaka, število alelov vključenih v izračun parametrov (n), standardni odklon (SD), variacijski razmik, razlika med povprečno dejansko dolžino določeno v slovenski (SI) in francoski (FR) raziskovalni skupini, razlika med dejansko dolžino po odstranjenem nukleotidnem zaporedju M13 (-21) začetnega oligonukleotida ter razlika med zaokroženimi vrednostmi dolžin na celo število z in brez podaljšanega zaporedja.

\begin{tabular}{|c|c|c|c|c|c|c|c|c|c|}
\hline \multirow[t]{2}{*}{ Locus } & Allele & $\begin{array}{l}\text { Average actual allele } \\
\text { sizes }\end{array}$ & \multirow[t]{2}{*}{$\begin{array}{l}\text { Letter } \\
\text { designation }\end{array}$} & \multirow[t]{2}{*}{$\mathrm{n}$} & SD & Range & \multirow[t]{2}{*}{$\begin{array}{l}\text { Differences in } \\
\text { actual sizes }\end{array}$} & \multirow{2}{*}{$\begin{array}{l}\text { Differences in } \\
\text { actual sizes } \\
\text { after removal } 18 \\
\text { or } 17 \mathrm{bp}\end{array}$} & \multirow{2}{*}{$\begin{array}{l}\text { Differences in called } \\
\text { allele sizes with and } \\
\text { without primer } \\
\text { elongation } \\
\text { sequences }\end{array}$} \\
\hline & FR group / SI group & FR group / SI group & & & FR group / SI group & FR group / SI group & & & \\
\hline \multirow[t]{5}{*}{ FSYC01 } & $117 / 137$ & $117.44 / 136.90$ & A & 19 & $0.05 / 0.03$ & $0.24 / 0.14$ & 19.45 & 2.45 & $20 / 3$ \\
\hline & $126 / 146$ & $126.04 / 146.02$ & $\mathrm{~B}$ & 7 & $0.03 / 0.06$ & $0.10 / 0.13$ & 19.98 & 2.98 & $20 / 3$ \\
\hline & $134 / 155$ & $134.46 / 154.99$ & $\mathrm{C}$ & 18 & $0.03 / 0.07$ & $0.13 / 0.23$ & 20.53 & 3.53 & $21 / 4$ \\
\hline & $152 / 172$ & $151.78 / 172.51$ & $\mathrm{D}$ & 2 & $0.07 / 0.00$ & $0.30 / 0.00$ & 20.72 & 3.72 & $20 / 3$ \\
\hline & $160 / 180$ & $160.13 / 180.38$ & E & 134 & $0.10 / 0.05$ & $0.55 / 0.23$ & 20.25 & 3.25 & $20 / 3$ \\
\hline \multirow{8}{*}{ LMFC30 } & $231 / 246$ & $230.45 / 245.73$ & $\mathrm{~A}$ & 3 & $0.04 / 0.005$ & $0.08 / 0.01$ & 15.28 & 1.71 & $15 /-2$ \\
\hline & $239 / 254$ & $238.80 / 253.60$ & $\mathrm{~B}$ & 4 & $0.09 / 0.06$ & $0.20 / 0.15$ & 14.80 & 2.20 & $15 /-2$ \\
\hline & $241 / 256$ & $240.86 / 255.68$ & $\mathrm{C}$ & 30 & $0.14 / 0.06$ & $0.51 / 0.25$ & 14.82 & 2.17 & $15 /-2$ \\
\hline & $247 / 262$ & $246.76 / 261.74$ & $\mathrm{D}$ & 3 & $0.40 / 0.07$ & $0.75 / 0.14$ & 14.98 & 2.02 & $15 /-2$ \\
\hline & $253 / 268$ & $253.13 / 267.79$ & E & 21 & $0.07 / 0.05$ & $0.26 / 0.20$ & 14.65 & 2.34 & $15 /-2$ \\
\hline & $255 / 270$ & $255.07 / 269.77$ & $\mathrm{~F}$ & 35 & $0.11 / 0.05$ & $0.52 / 0.21$ & 14.70 & 2.29 & $15 /-2$ \\
\hline & $257 / 272$ & $257.13 / 271.81$ & $\mathrm{G}$ & 46 & $0.08 / 0.05$ & $0.42 / 0.28$ & 14.68 & 2.31 & $15 /-2$ \\
\hline & $261 / 276$ & 261.24 / 275.91 & $\mathrm{H}$ & 38 & $0.15 / 0.04$ & $1.02 / 0.22$ & 14.66 & 2.33 & $15 /-2$ \\
\hline \multirow[t]{4}{*}{ MFC1 } & $177 / 195$ & $176.90 / 194.99$ & A & 69 & $0.10 / 0.05$ & $0.43 / 0.22$ & 18.08 & 1.08 & $18 / 1$ \\
\hline & $189 / 207$ & $189.49 / 207.00$ & B & 44 & $0.08 / 0.05$ & $0.29 / 0.21$ & 17.51 & 0.51 & $18 / 1$ \\
\hline & $192 / 210$ & $192.42 / 209.78$ & $\mathrm{C}$ & 13 & $0.10 / 0.04$ & $0.33 / 0.15$ & 17.36 & 0.16 & $18 / 1$ \\
\hline & $194 / 212$ & $194.37 / 211.64$ & $\mathrm{D}$ & 54 & $0.17 / 0.12$ & $0.99 / 0.71$ & 17.27 & 0.24 & $18 / 1$ \\
\hline \multirow[t]{5}{*}{ MFC2 } & $156 / 176$ & $155.83 / 176.25$ & A & 67 & $0.20 / 0.05$ & $0.77 / 0.31$ & 20.42 & 3.42 & $20 / 3$ \\
\hline & $158 / 178$ & $157.76 / 178.31$ & B & 7 & $0.17 / 0.09$ & $0.46 / 0.24$ & 20.55 & 3.55 & $20 / 3$ \\
\hline & 164 / 184 & $164.15 / 184.14$ & $\mathrm{C}$ & 16 & $0.08 / 0.04$ & $0.25 / 0.15$ & 19.99 & 2.99 & $20 / 3$ \\
\hline & $166 / 186$ & $166.24 / 186.15$ & $\mathrm{D}$ & 7 & $0.07 / 0.04$ & $0.21 / 0.12$ & 19.91 & 2.91 & $20 / 3$ \\
\hline & $170 / 191$ & $169.51 / 190.96$ & $\mathrm{E}$ & 83 & $0.18 / 0.04$ & $0.71 / 0.23$ & 21.44 & 4.44 & $21 / 4$ \\
\hline \multirow[t]{7}{*}{ MFC3 } & $104 / 123$ & $104.30 / 123.33$ & $\mathrm{~A}$ & 1 & $0.00 / 0.00$ & $0.00 / 0.00$ & 19.03 & 1.03 & $19 / 1$ \\
\hline & $120 / 139$ & $120.23 / 138.54$ & B & 17 & $0.04 / 0.04$ & $0.10 / 0.15$ & 18.31 & 0.31 & $19 / 1$ \\
\hline & $122 / 141$ & $122.42 / 140.94$ & $\mathrm{C}$ & 16 & $0.05 / 0.05$ & $0.17 / 0.19$ & 18.51 & 0.51 & $19 / 1$ \\
\hline & $124 / 143$ & $124.61 / 143.37$ & $\mathrm{D}$ & 13 & $0.07 / 0.04$ & $0.24 / 0.18$ & 18.75 & 0.75 & $19 / 1$ \\
\hline & $126 / 145$ & $126.43 / 145.43$ & $\mathrm{E}$ & 38 & $0.04 / 0.08$ & $0.18 / 0.49$ & 18.99 & 0.99 & $19 / 1$ \\
\hline & $136 / 155$ & $135.47 / 155.08$ & $\mathrm{~F}$ & 92 & $0.05 / 0.06$ & $0.23 / 0.52$ & 19.61 & 1.61 & $19 / 1$ \\
\hline & $142 / 162$ & $141.87 / 161.60$ & G & 2 & $0.02 / 0.00$ & $0.03 / 0.00$ & 19.72 & 1.72 & $20 / 2$ \\
\hline \multirow[t]{4}{*}{ MFC9 } & $192 / 209$ & $192.08 / 208.68$ & $\mathrm{~A}$ & 48 & $0.12 / 0.15$ & $0.38 / 0.51$ & 16.59 & 1.40 & $17 /-1$ \\
\hline & $198 / 215$ & $197.97 / 214.75$ & $\mathrm{~B}$ & 99 & $0.05 / 0.04$ & $0.28 / 0.25$ & 16.77 & 1.22 & $17 /-1$ \\
\hline & $204 / 221$ & $203.81 / 220.77$ & $\mathrm{C}$ & 3 & $0.07 / 0.11$ & $0.14 / 0.22$ & 16.96 & 1.04 & $17 /-1$ \\
\hline & $211 / 227$ & $209.70 / 226.65$ & D & 30 & $0.05 / 0.08$ & $0.24 / 0.45$ & 16.94 & 1.05 & $16 /-1$ \\
\hline
\end{tabular}




\subsection{Genotyping discrepancy}

In total, twenty-eight discrepancies $(2.6 \%)$ were observed and contributed only by heterozygous/homozygous misreadings. All genotyping discrepancies were detected at locus FSYC01; in all cases heterozygous genotypes were determined in the FR laboratory and homozygotes in the SI laboratory. In eighteen samples short allele dropout cases were observed: heterozygotes were genotyped with profile DE (152:160) and homozygotes with profile EE (180:180). Long allele dropout and amplification of the short allele only was observed in ten samples from three different genotypes: 1) heterozygotes: AD (117:152), homozygotes: AA (137:137)); 2) heterozygotes CD (134:152), homozygotes: CC (155:155); 3) heterozygotes: BD (126:152); homozygotes: BB (146:146). Common to all cases, was the failure of amplification of the D allele (152 bp / $172 \mathrm{bp}$ ), although in the homozygous state, this allele was normally amplified in both laboratories. Due to the detected discrepancies at this locus, the calculated mean error rate for FSYC01 was 0.1556 . On the other five loci, no allelic mismatches were discovered.

\subsection{Discriminatory power of microsatellite loci}

In order to estimate the discriminatory power of the loci used in the study, several variability parameters were calculated; the number of alleles, $\mathrm{H}_{\mathrm{o}}, \mathrm{H}_{\mathrm{e}}$, PI and PIC. All six microsatellite loci were polymorphic, revealing a total of 33 alleles with an average number of 5.5 alleles and an average of 3.1 effective alleles per locus (Table 1). The highest number of alleles (eight) was amplified on locus LMFC30, seven alleles were characteristic to locus MFC3, five alleles were found on loci MFC2 and FSYC01, and four alleles were characteristic to loci MFC9 and MFC1. Only one taxon specific allele A (104 bp (FR) / 123 bp (SI)) was found on locus MFC3 and was characteristic to the LBS16 fig genotype. In general, the number of effective alleles was relatively low, indicating that rare and frequent alleles are present in the examined population of samples. The highest number of effective alleles (5.25) was observed at locus LMFC30, where the frequencies of alleles were equally distributed.

At two loci, MFC3 and MFC9, three alleles were observed in the cultivar 'Belica' (SI / FR accesion code: 19F / SLCV06). At MFC3 the third allele length was $97 \mathrm{bp}$ (FR) / $117 \mathrm{bp}$ (SI). Since this allele was discovered only at this accession, it was discarded. At MFC9 all three alleles (SI allele lengths 209 / 215 / 227 bp; FR allele lengths 192 / 198 / 211 bp) were identified more than once, therefore we decided to exclude the longest allele from this analysis.
Expected heterozygosity varied between 0.539 (FSYC01) and 0.810 (LMFC30), with an average of 0.664. Similar values were obtained for observed heterozygosity, and were between 0.544 (FSYC01) and 0.833 (LMFC30).

The observed heterozygosity was higher than expected on four loci (MFC3, MFC9, LMFC30, and FSYC01 at the FR laboratory), showing an excess of heterozygotes, while excess of homozygotes was found on loci MFC1 and MFC2. An excess of homozygotes and a statistically significant deviation between expected and observed heterozygosity was also noted at locus FSYC01 $\left(\chi^{2}=14.35\right.$ (using Yates correction), $p<0.001$ ) calculated for the SI data set, where allele D (152 bp / $172 \mathrm{bp)}$ was not amplified and thus influences the variability statistics of this locus. Statistically significant deviation from HWE was observed for MFC1 as well $\left(\chi^{2}=12.73\right.$ (using Yates correction), $p<0.05$ ). As expected, the frequencies of null alleles for FSYC01 SI data and for locus MFC1 were higher due to the deviation from HWE. Since the null allele frequencies of MFC1 and FSYC01 for the SI data were between 0.05 and 0.2 , both loci were classified into the moderate class (Chapuis \& Estoup, 2007), while the null allele frequency calculated for other loci were negligible $\left(\mathrm{F}_{\text {null }}<0.05\right)$.

Calculated PIC values were in a range from 0.506 to 0.782 and classified all loci as informative markers (PIC > 0.5) and locus LMFC30 as suitable for mapping (PIC > 0.7). Regarding the probability of identity, the highest values were observed on loci MFC2, MFC9, and FSYC01. The minimum PI value (0.118) was calculated for loci LMFC30. The overall probability that the two samples in our study share the same genetic profile by chance was $2.66 \times 10^{-4}$ (calculated for the FR data).

\subsection{Fingerprinting and identification of reference cultivars}

The genotyping data of twenty-four Istrian cultivars over five microsatellite loci are presented in Table S4, however due to the high error rate of FSYC01 (0.1556) it is excluded from the table. Altogether, 27 different alleles were amplified over five loci in a set of 24 cultivars. The molecular analysis demonstrated the existence of 17 different genotypes. Microsatellite loci used in this study allowed discrimination of 11 cultivars, the remaining 13 were indistinguishable due to identical DNA profiles observed between five pairs of cultivars and one triple: 'Bela Petrovka' / 'Črna Petrovka', 'Črnica' / 'Rovinj', 'Pinčica' / 'Zelenka', 'Termenjača' / 'Zuccherina', 'Vodenjača' / 'Bružetka bela' and 'Cikulina' / 'Kanora' / 'Grška črna'. 
Analysis of discriminatory power of each combination of $k$ markers among $n$ available with AMaCAID program revealed that all 17 Istrian genotypes could be distinguished with only three loci (LMFC30, MFC1, and MFC9). With locus LMFC30 nine genotypes could be discriminated, while with loci LMFC30 and MFC1 and on the other hand with loci LMFC30, MFC1 and MFC9, 16 and 17 genotypes could be discriminated, respectively.

\section{DISCUSSION}

For successful evaluation of fig genetic resources and estimation of actual diversity of genotypes grown in specific geographical regions, the development and evaluation of proper genotyping protocols and construction of a database of the fig DNA profiles is necessary. This work requires collaboration between research groups and establishment of standardized protocols for the generation of easily comparable and interchangeable genotyping results.

In the present study we compared microsatellite genotyping data of fig trees generated in two different laboratories using their own protocols with the aim of comparing the data and the suitability of the used fig microsatellite loci for genotyping purposes. Ninety fig samples representing cultivars, feral, and wild figs were included in the analysis and genotyping was performed at six microsatellite loci proven to be suitable for discrimination of fig samples and genotyping cultivars (Ahmed et al., 2007; Giraldo et al., 2005; Khadari et al., 2001).

To introduce as much experimental variation as possible, each laboratory was allowed to optimize its own PCR condition and amplification protocols with their preferred supplier of chemicals (Table S1 and Table S2).

\subsection{Comparison of genotyping results}

Since instrument sensitivity is extremely important for interpretation, poor signal strength can result in poor morphology and potential for errors in sizing (Koumi et al., 2004). With the aim to assess similarity of electropherograms of the SI and FR groups, a comparison of peak morphology, signal strength, and peak balance were performed (Table 1, Figure 1, Figure 2). The lower signal intensity obtained by the SI group in comparison with the FR group may be due to the different PCR amplification protocols, different electrophoresis settings (e.g., injection time) and fluorescent dyes used for microsatellite labelling. Use of different fluorescent dyes has a strong impact on the results due to their different relative intensity values. Lower intensity dyes are also associated with the threeprimer protocol (Culley et al., 2013), where part of the amplified fragments remains unlabelled.
Lower fluorescent values did not have influence on the proper allele calling step of the SI laboratory electropherograms. The differences observed at the electropherograms allelic patterns between the SI and the FR laboratory did not influence genotyping either, since results were comparable and the distances between alleles of the same locus were consistent.

Peak balances of different allele pairs per each locus was comparable between laboratories, despite the different fluorescence values. Comparable peak balances were also obtained by Koumi et al. (2004), where they analysed comparability of the results of STR multiplex AmpFLSTR ${ }^{\mathrm{TM}}$ SGMplus ${ }^{\mathrm{TM}}$ (Thermo Fisher Scientific) (multiplex assay for human identification applications) between three different electrophoresis instruments (ABI 377, ABI 3700, ABI 3100).

Peak balance can be used in genetic studies as a threshold for determining two heterozygous alleles as a possible genotype, where values of $50 \%$ or $60 \%$ are typically used (calculated by dividing the weaker intensity allele peak height by the stronger intensity allele peak height) (Butler, 2014). Debernardi et al. (2011) observed that a threshold at $60 \%$ to be too stringent when analysing genotypes, obtained with AmpFLSTR $^{\mathrm{TM}}$ Identifiler $^{\mathrm{TM}}$ STR kit (Thermo Fisher Scientific), while in our study even a threshold at $50 \%$ would be too stringent at loci FSYC01, LMFC30, MFC2 and MFC3. However, at loci MFC1 and MFC9 a threshold at $60 \%$ could be applied.

Lower peak balance values indicate favourable amplification of the shortest allele. This phenomenon was most noticeable at loci LMFC30 and MFC3 with greater differences between short and long allelic combinations in heterozygous individuals. Such phenomenon can lead to a dropout effect of the longest allele (Tvedebrink et al., 2012), which is contributed by non-amplification of the allele. Analysis of peak balance in plant SSR genotyping studies is not the practice, but according to our opinion, it could improve the genotyping process because it helps to identify samples with larger deviations from the median and these should be checked once again with greater caution. 


\subsection{Comparison of allele length}

Comparison of the allele lengths (after removal of 17 or $18 \mathrm{bp}$ from the SI called allele lengths) showed differences between $2 \mathrm{bp}$ and $4 \mathrm{bp}$ which are in the range of previously reported investigations. This et al. (2004) have compared microsatellites of grape cultivars obtained from different laboratories, and mostly similar alleles were obtained, in some cases the raw data of identical alleles differed by as much as $5 \mathrm{bp}$. The differences are mainly contributed due to the use of different dyes, which contributes different molar weights to the final PCR products and due to the use of different molecular standards.

Standard deviation values of allele lengths were low, indicating that the sizing of identical alleles was very reproducible; differences among research groups could be assigned to different platform technologies used in the analysis. Differences in allele size are observed even if the same allele is repeatedly typed by the same CE machine (Pasqualotto et al., 2007). Very similar results have been obtained by Haberl \& Tautz (1999) in comparative allele sizing of microsatellites of honey bees $(0.05-0.17)$.

\subsection{Genotyping discrepancies}

Altogether twenty-eight discrepancies were observed, but all were a consequence of FSYC01 locus D allele dropout. We assume that this is an experimental problem, associated with the PCR protocol due to the tailed primers creating conditions that encourage competition between alleles and prevent amplification of some alleles. Different amplification temperature profiles, i.e. touchdown protocol used by SI group could also influence the amplification of the D allele, since increased specificity allowed by touchdown PCR protocol could cause allele dropout due to polymorphism in primer-binding sites (Mullins et al., 2007).

However, since long-allele dropout was observed in one sample, provided by FR group with DNA extracted with Dneasy Plant Mini Kit (Qiagen), we assume that different DNA extraction methods did not influence the $\mathrm{D}$ allele dropout, although it is known that different methods of DNA extraction can cause different results (Benjak et al., 2006).

According to Pompanon et al. (2005) error rates between $0.5 \%$ and $1 \%$ are common in many laboratories. In our study, this measure was calculated for locus FSYC01 only, where the allelic dropout was the main cause of error. Due to the high mean error rate $(15.56 \%)$ associated with locus FSYC01 it should be considered as error-prone and thus its use in identification studies is unreliable.

\subsection{Diversity parameters of selected microsatellite loci}

Six microsatellite loci used in this study were chosen based on their confirmed discriminatory power and ease of scoring as observed in previous studies. In the study of Achtak et al. (2009) selected loci demonstrated higher discriminating power, while a combination of loci LMFC30, MFC2, MFC3, FSYC01 and MFC9 was able to discriminate all 75 accessions (except one pair) from Moroccan fig collection. All six loci exhibited higher discriminating power in the analysis of 277 cultivated trees from Morocco (Achtak et al., 2010).

Selected microsatellite loci were tested on a genetically diverse plant material, which was confirmed with high He values (from 0.598 to 0.810 ). Similar values for the selected loci were obtained from the several fig collections including: the ELGO 'Demeter' collection in Greece (with accessions from different Mediterranean countries) (Ganopoulos et al., 2015), local Turkish fig accessions (Caliskan et al., 2012), and a Morrocan fig collection (Achtak et al., 2009). Lower values were obtained by Abdelkrim et al. (2015) when analysing wild and cultivated Tunisian figs.

According to the diversity parameters all microsatellite loci analyzed in this study (except FSYC01, which was identified as unreliable) are suitable for fig cultivar characterization. They exhibit high PIC values (from 0.534 to 0.782 ), which classified them as informative molecular markers. The total probability of identity calculated with five SSR loci (without locus FSYC01) was $8.47 \times 10^{-4}$ and it is comparable with other fig fingerprinting studies. Giraldo et al. (2005) obtained a total PI of $6.8 \times 10^{-4}$ when analyzing 209 fig accessions from Spain with 11 microsatellite loci. In a previously mentioned study of Achtak et al. (2009) calculated total PI for six loci, that were able to discriminate all 75 accession, was $2.3 \times 10^{-4}$. However, due to the high mean error rate observed at locus FSYC01, we suggest replacing it in future sets of microsatellite markers.

At two loci, MFC3 and MFC9, three alleles were observed in the cultivar 'Belica'. Amplification of more than two alleles in diploid agricultural plants is rather common due to conservation of sequences through the eukaryotic genome and the presence of duplicated loci. Cipriani et al. (2002) have found $17 \%$ out of 30 developed loci in olive cultivars to amplify two different loci. In fig trees, Giraldo et al. (2008) reported amplification of more than two markers in some genotypes on $45 \%$ of tested loci. Such loci are usually discarded from analysis or they are marked as only partially suitable for comparison studies, but since in our study third allele was observed only in one sample 
both loci were recognized as reliable for fig genotyping studies.

\subsection{Reference allele sizes for Istrian cultivars}

Genotyping results of 24 reference cultivars from the Istrian peninsula, confirmed by the SI and FR research groups, can serve as a reference for identification purposes, fig collection management, and for standardising fig genotyping projects from the Balkan and surrounding regions.

Using the selected set of five microsatellite loci eleven out of twenty-four cultivars were distinguishable. The possibility of synonyms for 'Cikulina', 'Kanora' and 'Grška črna' / 'Termenjača' and 'Zuccherina' / 'Vodenjača' and 'Bela Bružetka' was already observed with a different set of loci of FCUP series (Bandelj et al., 2007, 2008). Interestingly, using the selected microsatellite primers in this study we were not able to distinguish between 'Pinčica' and 'Zelenka', or 'Črnica' and 'Rovinj', which were already discriminated with loci FCUP44-6 and FCUP66-7 or FCUP62-2 and FCUP66-7, respectively (Bandelj et al., 2008). The varieties 'Bela Petrovka' and 'Črna Petrovka' were not discriminated on a DNA level, while it is known that they are different varieties, since 'Bela Petrovka' produces fruits with green skin and 'Črna Petrovka' produces fruits with brown green skin.

A minimum set of loci (LMFC30, MFC1, MFC9) was determined to be sufficient to identify all 17 genotypes among the 24 reference cultivars examined in this study. This set of loci can be used for preliminary screening of fig genetic resources, while for discrimination of all 24 reference cultivars additional microsatellite loci should be utilized.

\section{CONCLUSIONS}

The analysis performed in this study showed that the comparability of allele sizes between two laboratories was very good and deviations in allele sizes were in the expected range, although different PCR technology, chemicals, and laboratory machinery were used. Coding alleles with letters, after the results standardisation, simplified genotypes comparisons. The published allele sizes of 24 reference cultivars from the Istrian peninsula (north-east Adriatic coast) in this work will serve for standardisation of new genotyping projects. The defined minimum subset of markers represents a step toward efficient identification of fig genetic resources in other fig growing countries. Such studies are essential because they enable identification of error prone loci under different PCR technologies. The high error rate encountered with Locus FSYC01 (15.56\%) indicated it should be excluded from genotyping projects. All other loci were identified as reliable for fig genotyping studies.

A very important goal which can be achieved with standardized molecular identification tools is the identification of unique local genotypes. This would support management of fig collections and promote cultivation and breeding of new and interesting cultivars, either through exchanging and introducing different cultivars in new regions or to give importance to newly identified local unique cultivars. Traditional local products with protected designation of origin or with other quality schemes are in great demand and genetic analysis can help to identify cultivars which are characteristic for a specific geographical region.

\section{ACKNOWLEDGMENTS}

This work is part of bilateral project Slovenia-France and was supported by the Slovenian Research Agency [BI-FR / 09-10-INRA-001].

\section{SUPPLEMENTARY MATERIAL}

The supplementary material for this article can be found online at the repository at University of Primorska. 


\section{REFERENCES}

Abdelkrim, A. B., Baraket, G., Essalouh, L., Achtak, H., Khadari, B., \& Salhi-Hannachi, A. (2015). Use of morphological traits and microsatellite markers to characterize the Tunisian cultivated and wild figs (Ficus carica L.). Biochemical Systematics and Ecology, 59, 209-219. doi:10.1016/j.bse.2015.01.026

Abou-Ellail, M., Mahfouze, S. A., El-Enany, M. A. M., \& Mustafa, N. S. A. (2014). Using biochemical and simple sequence repeats (SSR) markers to characterize (Ficus carica L.) cultivars. World Applied Sciences Journal, 29(3), 313-321. https://doi:10.5829/idosi.wasj.2014.29.03.13835

Achtak, H., Oukabli, A., Ater, M., Santoni, S., Kjellberg, F., \& Khadari, B. (2009). Microsatellite markers as reliable tools for fig cultivar identification. Journal of the American Society for Horticultural Science, 134(6), 624-631.

Achtak, H., Ater, M., Oukabli, A., Santoni, S., Kjellberg, F., \& Khadari, B. (2010). Traditional agroecosystems as conservatories and incubators of cultivated plant varietal diversity: the case of fig (Ficus carica L.) in Morocco. BMC Plant Biology, 10(1), 28. doi:10.1186/1471-2229-10-28

Ahmed, S., Dawson, D. A., Compton, S. G., \& Gilmartin, P. M. (2007). Characterization of microsatellite loci in the African fig Ficus sycomorus L. (Moraceae). Molecular Ecology Notes, 7(6), 1175-1177. doi:10.1111/j.14718286.2007.01822.x

Aradhya, M. K., Stover, E., Velasco, D., \& Koehmstedt, A. (2010). Genetic structure and differentiation in cultivated fig (Ficus carica L.). Genetica, 138(6), 681-694. doi:10.1007/s10709-010-9442-3

Balas, F. C., Osuna, M. D., Domínguez, G., PérezGragera, F., \& López-Corrales, M. (2014). Ex situ conservation of underutilised fruit tree species: establishment of a core collection for Ficus carica L. using microsatellite markers (SSRs). Tree Genetics \& Genomes, 10(3), 703-710. doi:10.1007/s11295-014-0715-3

Baldoni, L., Cultrera, N., Mariotti, R., Ricciolini, C., Arcioni, S., Vendramin, G., . . Testolin, R. (2009). A consensus list of microsatellite markers for olive genotyping. Molecular Breeding, 24(3), 213-231. doi:10.1007/s11032-009-9285-8

Bandelj, D., Jakše, J., \& Javornik, B. (2004). Amplification of fluorescent-labelled microsatellite markers in olives by a novel, economic method. Acta agriculturae Slovenica, 83(2), 323-329.
Bandelj, D., Javornik, B., \& Jakše, J. (2007). Development of microsatellite markers in the common fig, Ficus carica L. Molecular Ecology Notes, 7(6), 1311-1314. doi:10.1111/j.14718286.2007.01866.x

Bandelj, D., Jakše, J., Javornik, B. (2008). Development of molecular markers for identification of fig varieties in Istria. In D. Bandelj, M. BučarMiklavčič \& I. Vrhovnik (Eds.), The common fig (Ficus carica L.) in Istria: morphological, molecular and some chemical characteristics (pp. 84-89). Koper, SI: Annales.

Benjak, A., Konradi, J., Blaich, R., \& Forneck, A. (2006). Different DNA extraction methods can cause different AFLP profiles in grapevine (Vitis vinifera L.). Vitis, 45(1), 15-21.

Butler, J. M. (2014). Advanced Topics in Forensic DNA Typing: Interpretation (1st ed.). San Diego, CA: Academic Press.

Caliskan, O., Polat, A. A., Celikkol, P., \& Bakir, M. (2012). Molecular characterization of autochthonous Turkish fig accessions. Spanish Journal of Agricultural Research, 10(1), 130-140. doi:10.5424/sjar/2012101-094-11

Caroli, S., Santoni, S., \& Ronfort, J. (2011). AMaCAID: a useful tool for accurate marker choice for accession identification and discrimination. Molecular Ecology Resources, 11(4), 733-738. doi:10.1111/j.1755-0998.2011.02993.x

Chapuis, M. P., \& Estoup, A. (2007). Microsatellite null alleles and estimation of population differentiation. Molecular Biology and Evolution, 24(3), 621-631. doi:10.1093/molbev/msl191

Chatti, K., Baraket, G., Abdelkrim, A. B., Saddoud, O., Mars, M., Trifi, M., \& Salhi Hannachi, A. (2010). Development of molecular tools for characterization and genetic diversity analysis in Tunisian fig (Ficus carica) cultivars. Biochemical Genetics, 48(9-10), 789-806. doi:10.1007/s10528010-9360-1

Cipriani, G., Marrazzo, M. T., Marconi, R., Cimato, A., \& Testolin, R. (2002). Microsatellite markers isolated in olive (Olea europaea L.) are suitable for individual fingerprinting and reveal polymorphism within ancient cultivars. TAG Theoretical and Applied Genetics, 104(2), 223-228. doi:10.1007/s001220100685

Cryer, N., Fenn, M., Turnbull, C., \& Wilkinson, M. (2006). Allelic size standards and reference genotypes to unify international cocoa (Theobroma 
Interlaboratory comparison of fig (Ficus carica L.) microsatellite genotyping data and determination of reference alleles

cacao L.) microsatellite data. Genetic Resources and Crop Evolution, 53(8), 1643-1652. doi:10.1007/s10722-005-1286-9

Culley, T. M., Stamper, T. I., Stokes, R. L., Brzyski, J. R., Hardiman, N. A., Klooster, M. R., \& Merritt, B. J. (2013). An efficient technique for primer development and application that integrates fluorescent labeling and multiplex PCR. Applications in Plant Sciences, 1(10), 1300027. doi:10.3732/apps.1300027

De Valk, H. A., Meis, J. F. G. M., Bretagne, S., Costa, J. M., Lasker, B. A., Balajee, S. A.,. Klaassen, C. H. W. (2009). Interlaboratory reproducibility of a microsatellite-based typing assay for Aspergillus fumigatus through the use of allelic ladders: proof of concept. Clinical Microbiology and Infection, 15(2), 180-187. doi:10.1111/j.14690691.2008.02656.x

Debernardi, A., Suzanne, E., Formant, A., Pène, L., Dufour, A. B., \& Lobry, J. R. (2011). One year variability of peak heights, heterozygous balance and inter-locus balance for the DNA positive control of AmpFLSTR Identifiler STR kit. Forensic Science International: Genetics, 5(1), 43-49. doi:10.1016/j.fsigen.2010.01.020

Deemer, D. L., \& Nelson, D. C. (2010). Standardized SSR allele naming and binning among projects. BioTechniques, $\quad 49, \quad 835-836$. doi:10.2144/000113540

Doveri, S., Sabino Gil, F., Díaz, A., Reale, S., Busconi, M., da Câmara Machado, A., . . . Lee, D. (2008). Standardization of a set of microsatellite markers for use in cultivar identification studies in olive (Olea europaea L.). Scientia Horticulturae, 116(4), 367-373. doi:10.1016/j.scienta.2008.02.005

Ellis, J. S., Gilbey, J., Armstrong, A., Balstad, T., Cauwelier, E., Cherbonnel, C., . . . Stevens, J. R. (2011). Microsatellite standardization and evaluation of genotyping error in a large multipartner research programme for conservation of Atlantic salmon (Salmo salar L.). Genetica, 139(3), 353-367. doi:10.1007/s10709-011-9554-4

Ganopoulos, I., Xanthopoulou, A., Molassiotis, A., Karagiannis, E., Moysiadis, T., Katsaris, P., . . . Madesis, P. (2015). Mediterranean basin Ficus carica L.: from genetic diversity and structure to authentication of a Protected Designation of Origin cultivar using microsatellite markers. Trees, 29(6), 1959-1971. doi:10.1007/s00468-015-1276-2

Giraldo, E., Viruel, M. A., López-Corrales, M., \& Hormaza, J. I. (2005). Characterisation and crossspecies transferability of microsatellites in the common fig (Ficus carica L.). Journal of
Horticultural Science and Biotechnology, 80(2), 217-224. doi:10.1080/14620316.2005.11511920

Giraldo, E., Lopez-Corrales, M., \& Hormaza, J. I. (2008). Optimization of the management of an exsitu germplasm bank in common fig with SSRs. Journal of the American Society for Horticultural Science, 133(1), 69-77.

Haberl, M., \& Tautz, D. (1999). Comparative allele sizing can produce inaccurate allele size differences for microsatellites. Molecular Ecology, 8(8), 13471349. doi:10.1046/j.1365-294X.1999.00692_1.x

Ikegami, H., Nogata, H., Hirashima, K., Awamura, M., \& Nakahara, T. (2009). Analysis of genetic diversity among European and Asian fig varieties (Ficus carica L.) using ISSR, RAPD, and SSR markers. Genetic Resources and Crop Evolution, 56(2), 201-209. doi:10.1007/s10722-008-9355-5

Jones, H., Bernole, A., Jensen, L., Horsnell, R., Law, J., Cooke, R., \& Norris, C. (2008). Minimising interlaboratory variation when constructing a unified molecular database of plant varieties in an allogamous crop. TAG Theoretical and Applied Genetics, 117(8), 1335-1344. doi:10.1007/s00122008-0867-3

Kalinowski, S. T., Taper, M. L., \& Marshall, T. C. (2007). Revising how the computer program CERVUS accommodates genotyping error increases success in paternity assignment. Molecular Ecology, 16(5), 1099-1106. doi:10.1111/j.1365-294X.2007.03089.x

Khadari, B., Hochu, I., Santoni, S., \& Kjellberg, F. (2001). Identification and characterization of microsatellite loci in the common fig (Ficus carica L.) and representative species of the genus Ficus. Molecular Ecology Notes, 1(3), 191-193. doi:10.1046/j.1471-8278.2001.00072.x

Khadari, B., Oukabli, A., Ater, M., Mamouni, A., Roger, J. P., \& Kjellberg, F. (2005). Molecular characterization of Moroccan fig germplasm using intersimple sequence repeat and simple sequence repeat markers to establish a reference collection. HortScience, 40(1), 29-32.

Khadari, B. (2012). Ex situ management of fig (Ficus carica L.) genetic resources: Towards the establishment of the Mediterranean reference collection. Acta Horticulturae, 940, 67-74. doi:10.17660/ActaHortic.2012.940.7

Koumi, P., Green, H. E., Hartley, S., Jordan, D., Lahec, S., Livett, R. J., . . W Ward, D. M. (2004). Evaluation and validation of the ABI $3700, \mathrm{ABI} 3100$, and the MegaBACE 1000 capillary array electrophoresis instruments for use with short tandem repeat microsatellite typing in a forensic environment. 
Matjaž HLADNIK et al.
Electrophoresis, doi:10.1002/elps.200305976

Kump, B., \& Javornik, B. (1996). Evaluation of genetic variability among common buckwheat (Fagopyrum esculentum Moench) populations by RAPD markers. Plant Science, 114(2), 149-158. doi:10.1016/0168-9452(95)04321-7

Kyung-Ho, M., Nam-Soo, K., Gi-An, L., Sok-Young, L., Ju Kyong, L., Jung Yoon, Y., . . . Soon-Jae, K. (2009). Development of SSR markers for studies of diversity in the genus Fagopyrum. Theoretical and Applied Genetics, 119(7), 1247-1254. doi:10.1007/s00122-009-1129-8

Leclair, B., Fregeau, C., Bowen, K., \& Fourney, R. (2004). Systematic analysis of stutter percentages and allele peak height and peak area ratios at heterozygous STR loci for forensic casework and database samples. Journal of Forensic Sciences, 49(5), 968-980. doi:10.1520/JFS2003312

Mandel, J. R., Dechaine, J. M., Marek, L. F., \& Burke, J. M. (2011). Genetic diversity and population structure in cultivated sunflower and a comparison to its wild progenitor, Helianthus annuus L. Theoretical and Applied Genetics, 123(5), 693-704. doi:10.1007/s00122-011-1619-3

Mullins, F. M., Dietz, L., Lay, M., Zehnder, J. L., Ford, J., Chun, N., \& Schrijver, I. (2007). Identification of an intronic single nucleotide polymorphism leading to allele dropout during validation of a CDH1 sequencing assay: implications for designing polymerase chain reaction-based assays. Genetics In Medicine, 9 , 752. doi:10.1097/GIM.0b013e318159a369

Nybom, H., Weising, K., \& Rotter, B. (2014). DNA fingerprinting in botany: past, present, future. Investigative Genetics, 5(1), 1-35. doi:10.1186/2041-2223-5-1

Pasqualotto, A. C., Denning, D. W., \& Anderson, M. J. (2007). A cautionary tale: Lack of consistency in allele sizes between two laboratories for a published multilocus microsatellite typing system. Journal of Clinical Microbiology, 45(2), 522-528. doi:10.1128/JCM.02136-06

Peakall, R., \& Smouse, P. E. (2006). GENEALEX 6: genetic analysis in Excel. Population genetic software for teaching and research. Molecular Ecology Notes, 6(1), 288-295. doi:10.1111/j.14718286.2005.01155.x

Peakall, R., \& Smouse, P. E. (2012). GenAlEx 6.5: genetic analysis in Excel. Population genetic software for teaching and research-an update.
Bioinformatics, 28(19),
doi:10.1093/bioinformatics/bts460

2537-2539.

Pompanon, F., Bonin, A., Bellemain, E., \& Taberlet, P. (2005). Genotyping errors: causes, consequences and solutions. Nature Reviews Genetics, 6(11), 847859. doi:10.1038/nrg1707

Schuelke, M. (2000). An economic method for the fluorescent labeling of PCR fragments. Nature Biotechnology, 18(2), 233-234. doi:10.1038/72708

Solomon, A., Golubowicz, S., Yablowicz, Z., Grossman, S., Bergman, M., Gottlieb, H. E., . . . Flaishman, M. A. (2006). Antioxidant activities and anthocyanin content of fresh fruits of common fig (Ficus carica L.). Journal of Agricultural and Food Chemistry, 54(20), 7717-7723. doi:10.1021/jf060497h

Soriano, J., Zuriaga, E., Rubio, P., Llácer, G., Infante, R., \& Badenes, M. (2011). Development and characterization of microsatellite markers in pomegranate (Punica granatum L.). Molecular Breeding, 27(1), 119-128. doi:10.1007/s11032-0109511-4

Sutton, J. T., Robertson, B. C., \& Jamieson, I. G. (2011). Dye shift: a neglected source of genotyping error in molecular ecology. Molecular Ecology Resources, 11, 514-520. doi:10.1111/j.17550998.2011.02981.x

This, P., Jung, A., Boccacci, P., Borrego, J., Botta, R., Costantini, L., . . . Maul, E. (2004). Development of a standard set of microsatellite reference alleles for identification of grape cultivars. TAG Theoretical and Applied Genetics, 109, 1448-1458. doi:10.1007/s00122-004-1760-3

Tvedebrink, T., Eriksen, P. S., Mogensen, H. S., \& Morling, N. (2012). Statistical model for degraded DNA samples and adjusted probabilities for allelic drop-out. Forensic Science International: Genetics, 6(1), 97-101. doi:10.1016/j.fsigen.2011.03.001

Vemireddy, L. R., Archak, S., \& Nagaraju, J. (2007). Capillary electrophoresis is essential for microsatellite marker based detection and quantification of adulteration of Basmati rice (Oryza sativa). Journal of Agricultural and Food Chemistry, 55(20), 8112-8117. doi:10.1021/jf0714517

Vinson, J. A., Zubik, L., Bose, P., Samman, N., \& Proch, J. (2005). Dried fruits: excellent in vitro and in vivo antioxidants. Journal of the American College of Nutrition, 24(1), 44-50. doi:10.1080/07315724.2005.10719442 
Interlaboratory comparison of fig (Ficus carica L.) microsatellite genotyping data and determination of reference alleles

Wagner, H. W., \& Sefc, K. M. (1999). IDENTITY 1.0. Vienna, AT: University of Agricultural Sciences, Centre for Applied Genetics.

Wenz, H. M., Robertson, J. M., Menchen, S., Oaks, F., Demorest, D. M., Scheibler, D., . . Efcavitch, J. W. (1998). High-precision genotyping by denaturing capillary electrophoresis. Genome Research, 8(1), 69-80. doi:10.1101/gr.8.1.69

Zohary, D., \& Spiegel-Roy, P. (1975). Beginnings of fruit growing in the old world. Science, 187(4174), 319-327. doi:10.1126/science.187.4174.319 